\title{
Production and Quality Evaluation of Flavoured Yoghurt from Graded Levels of Sweet Variety of African Bush Mango "Ugiri" (Irvingia gabonensis) Juice and Pulp
}

\author{
Mbaeyi-Nwaoha I. E. , Umeh L. C., Igbokwe C. J., Obodoechi C. M., Okoronkwo N. C. \\ Department of Food Science and Technology, University of Nigeria, Nigeria
}

Copyright $\subset 2017$ by authors, all rights reserved. Authors agree that this article remains permanently open access under the terms of the Creative Commons Attribution License 4.0 International License

\begin{abstract}
Yoghurt was produced and flavoured with graded levels of African bush mango juice (ABMJ) and pulp (ABMP). African bush mango (Irvingia gabonensis) juice and pulp was used to substitute $0,10,20,30,40$ and $50 \%$ of yoghurt. The chemical, sensory and microbiological properties of the yoghurts were determined using standard procedures. The results showed that the $\mathrm{pH}$ of the yoghurt ranged from 4.77 to 5.01. Plain yoghurt (PY) served as the control. The protein, ash, fat and fibre contents decreased with increase in African bush mango juice and pulp while the moisture content increased with increase in African bush mango juice. Micro-nutrient (vitamin A and $\mathrm{C}$ ) increased with increased level of African bush mango juice and pulp in the yoghurt while (phosphorus and calcium) decreased with increased level of African bush mango juice and pulp in the yoghurt. The reducing sugar increased with increased level African bush mango juice and pulp content of the formulated yoghurt. The total viable count and lactic acid bacteria ranged from $1.2 \times 10^{5}$ to $2.7 \times 10^{5} \mathrm{cfu} / \mathrm{ml}$ and $7.5 \times 10^{4}$ to $1.2 \times 10^{5} \mathrm{cfu} / \mathrm{ml}$ respectively. High mean values (7.95) were obtained for the plain yoghurt (control) for all sensory attributes (colour, flavour, taste, aftertaste, consistency and mouth feel) therefore making the sample (PY) most preferred sample with an overall acceptability of 7.95. Sample (PY+ ABMP) 90:10 had the highest mean for general acceptability (6.70) compared to the other flavoured yoghurt samples and was second in overall preference. Samples containing 10, 20,30\% of African bush mango juice in yoghurt were generally acceptable while samples containing 40 and $60 \%$ of the juice were generally unacceptable. Samples containing 10 and $20 \%$ of African bush mango pulp in yoghurt were generally acceptable while samples containing 30,40 and $50 \%$ of the juice were generally unacceptable. There was no significant $(\mathrm{p}<0.05)$ difference between the plain yoghurt and the flavoured yoghurt sample containing 10\% African bush mango juice while the difference with the flavoured yoghurt containing $10 \%$ African bush mango pulp was significant $(\mathrm{p}<0.05)$.
\end{abstract}

Keywords African Bush Mango (Irvingia gabonensis), Flavoured Yoghurt, Juice, Pulp

\section{Introduction}

Yoghurt is a diary product produced by bacterial fermentation of milk (addition of a starter of active yoghurt containing a mixed culture). The bacteria used to make yoghurt are known as yoghurt cultures. These cultures include Streptococcus salivarius subspecies thermophilus and Lactobacillus delbrueckii subspecies bulgaricus. Fermentation of lactose by these bacteria produces lactic acid, which acts on milk protein to give yoghurt its texture and characteristic tang [1]. The lactic acid lowers the $\mathrm{pH}$, makes it tart, causes the milk protein to thicken and acts as a preservative since pathogenic bacteria cannot grow in acid condition. The decrease in $\mathrm{pH}$ inhibits the growth of pathogenic bacteria. The lactic acid produced is also responsible for the characteristic flavour and aroma of yoghurt and helps to maintain the quality of the yoghurt during storage and packaging [2]. The partial digestion of the milk when these bacteria ferment milk makes yoghurt easily digestible [3]. The fermented milk could be blended with various ingredients like fruits which provide favour and colour.

Yoghurt is a very versatile food stuff, which is eaten both as a food on its own or ingredient in other foods. It is a probiotic product since it contains live active micro-organisms which upon ingestion in sufficient number exert health benefits beyond the inherent basic nutrition and it can be used in marinades, dips, sauces, dressing, baked goods, chilled and frozen dessert amongst others [4].

However milk, the major ingredient in yoghurt production, is manufactured by a number of animals, although in terms of commercial quantity milk from cow is the most popular. Cow's milk protein which comprises mainly of casein is 
most commonly used to make yoghurt but milk from goat, water buffalo, ewe, mares, camels and yaks can also be used. Goat milk has been reported to be a good raw material for yoghurt processing as it compared well with cow milk in terms of nutrient composition $[5,6]$. The fermentation of milk to yoghurt takes a relatively short period of time, 3 - 4 hours because it is done at higher temperature $\left(42-46^{\circ} \mathrm{C}\right)$ and also uses cultures that have fast growth rates. The major fermentation product is lactic acid, which is responsible for coagulation of the milk caseins. Other metabolites that are responsible for the yoghurt flavour are also produced during the fermentation and these include diacetyl, acetaldehyde and acetone.

In the production of yoghurt, skimmed milk is mixed with whole or full cream milk and heated at $82-93^{\circ} \mathrm{C}$ for $30-60$ minutes to destroy pathogenic/spoilage micro-organisms and to destabilize Kappa-casein. It is inoculated with a mixed culture of Lactobacillus bulgaricus and Streptococcus thermophilus. Initially, S. thermophilus grows rapidly to produce diacetyl, lactic, acetic and formic acids [7]. L. bulgaricus possesses weak protease activity which releases peptides from the milk proteins. These stimulate the growth of $S$. thermophilus [7]. The increased acidity then slows down the growth of $S$. thermophilus and promotes $L$. bulgaricus, which is stimulated by formate produced in the initial stage. L. bulgaricus produces most of the lactic acid and acetaldehyde which together with diacetyl, gives the characteristic flavour and aroma in yoghurt [7]. To modify certain properties of yoghurt ingredients like fruits are added to the fermentation media to increase the organoleptic properties. Presently, only flavoured yoghurts from exotic fruits such as raspberry, banana, peach, vanilla, and strawberry are commercially available.

However, there are some underutilized tropical fruits that can be used in place of these exotic ones for instance; African bush mango "Ugiri" (Irvingia garbonensis) can also be used in flavouring yoghurt. African bush mango (Irvingia garbonensis) is a fruit and a member of the family Irvingiaceae that grows in tropical rain-forests along the African Atlantic coast. The kernels of its seeds are used as a thickener. African bush mango (Irvingia gabonensis) is the Latin name of the tree grown in Central and West Africa that produces a fruit similar to a mango and nicknamed African mango, wild mango, dika nut, or bush mango. There are two varieties of African bush Mango grown. One has sweet, edible fruit (Irvingia gabonensis); the other variety has inedible, bitter, sour fruit (Irvingia wombolu). It is very hard to distinguish between the two trees until they bear fruit. Both trees need up to 10 years of growth before they fruit. They have leaves $21 / 2$ to 4 inches $(6$ to $10 \mathrm{~cm}$ ) long. The sweet, edible fruit is about 2 to 3 inches wide $(5$ to $7.5 \mathrm{~cm}$ ), ripening from green to yellow. The sweet fruit is fibrous, and can be made into juice or jam [8] and wine [9].

Meanwhile, the ripe fruit pulp of Var. gabonensis is not just consumed for its nutrients, flavour and aroma but also for its medicinal value. It has been claimed that consumption of bush mango whitens the teeth [10]. The pulp of the fruit of Irvingia gabonensis is juicy, sweet and eaten fresh. It can be used for the preparation of juice, jelly, jam and wine. The pulp has also been used to prepare a black dye for cloth. The main flavour components of the fruit pulp are zingiberene and $\alpha$-curcumene, ethyl and methyl esters of cinnamic acid, dodecanal and decanol imparting spicy-earthy, fruity and wine-yeast flavour notes. The fruit pulp yields about $75 \%$ juice and wine produced from it was found to be of good colour, mouthfeel, flavour and general acceptability. The fruit pulp is a rich source of carbohydrate and contains significant amounts of iron, thiamine, niacin, calcium, magnesium, fat and protein [11]. It also has many therapeutic and nutritive properties. However, the ripe fruits are highly perishable or susceptible to spoilage. To prevent this spoilage and as such improve the use of the nutritive and therapeutic properties of the fruit, African bush mango could be used as a flavouring agent in yoghurt production. When incorporated into yoghurt, the fruit would add to the nutritional quality of the product by providing essential vitamins and minerals. It would also contribute to the protein and calorific value of the product. Addition of African bush mango would improve the taste of the yoghurt and the micronutrient requirements of the consumers, thus increasing the general acceptability of yoghurt flavoured with African bush mango.

Meanwhile, the major challenges are that yoghurt is produced from milk which contains a reasonable amount of live cultures mainly bacteria. The bacteria used can be affected by other bacteria that might be on dishes and utensils. Firstly, yoghurt is made from fermented milk. Milk is rich in sugars, more specifically being lactose. An environment rich in sugars is an environment that microbes love to thrive in; thus milk is a great feast for microbes [12]. The presence of other bacteria could lead to production of undesirable product and a product with low shelf life. Starter culture which is the major raw material for yoghurt production is sometimes very difficult to obtain, especially in its active starter culture [13].

Furthermore, most Nigerian fruits are seasonal. These tropical fruits undergo post-harvest losses because of poor storage condition, handling, pest attack, disease and deterioration. According to [14], processing reduces post-harvest losses and spread the availability throughout the year. They are abundant during their season (wet season) and as such most of them are wasted or lost either to spoilage or pests. To avoid these postharvest losses, these fruits (for instance African bush mango) could be incorporated into yoghurt as a flavouring agent. African bush mango, which is one of the fruits neglected, is highly nutritious and therapeutic. As such, its use as a flavourant in yoghurt (which is the most widely consumed fermented dairy product), would increase the number of consumers that derive from the enormous benefits of African bush mango. Problems could be encountered when adding the flavouring agent if the correct amount to be added is not known [15]. 
Therefore, the main aim of this study was to produce and evaluate yoghurt, flavoured with graded levels of African bush mango pulp.

\section{Materials and Methods}

\subsection{Source of Raw Materials}

The African bush mango (sweat variety), "ugiri" (Irvingia gabonensis) was obtained from Nkwo Ibagwa market while skimmed milk, starter culture (yoghurmet), sugar and stabilizer were purchased from Ogige main market both in Nsukka local Government area of Enugu State, Nigeria.

\subsubsection{African bush mango Fruit Juice Production}

The African bush mango fruit was processed according to [16] procedure. The African bush mango fruits were sorted to remove the bad ones after which they were washed and peeled. Fruit juice was extracted using a juice extractor (Pulping machine) and pasteurized for $85{ }^{\circ} \mathrm{C}$ for 3 minutes. The juice was then cooled. The flow chart for African bush mango juice production is shown in Figure 1.

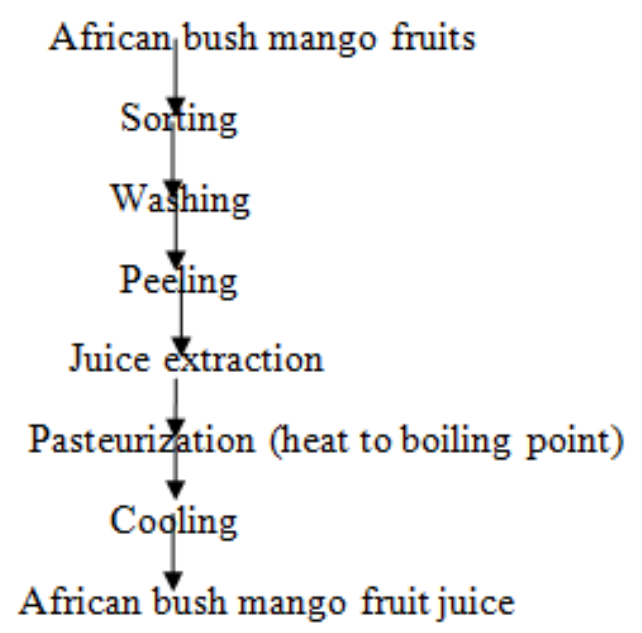

Figure 1. Production of African bush mango fruit juice. Source: Woodroff and Luh (1986).
2.1.2. Production of African Bush Mango Flavoured Yoghurt

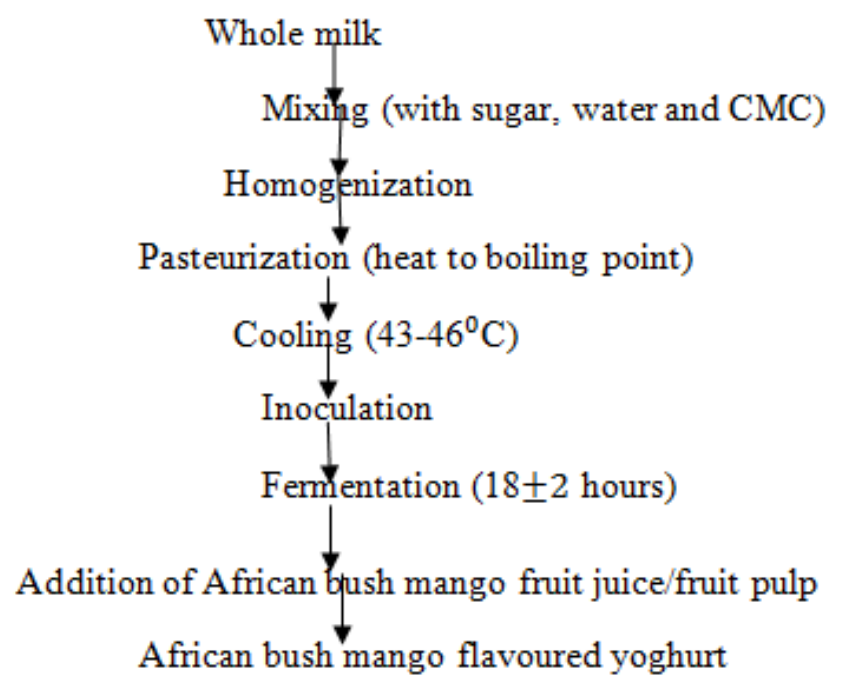

Figure 2. Production of flavoured yoghurt with African bush mango fruit juice

The African bush mango fruit flavoured yoghurt was produced as follows: the raw materials (whole milk, carboxymethyl cellulose, CMC and sugar) were appropriately weighed and mixed with water. The mixed product was then homogenized to obtain a creamy and uniform product. Pasteurization was then carried out at $85^{\circ} \mathrm{C}$ for 30 minutes as shown in Figure 2 to destroy the undesirable microorganism (pathogenic and spoilage microorganisms) in the raw materials to provide a favour environment free from competition for the growth of the starter culture. The product was then cooled to a temperature of $43-46^{\circ} \mathrm{C}$ which is the ideal growth temperature of the starter culture. The African bush mango fruit pulp/ juice was added. The starter inoculated. Fermentation was then carried out for 18 hours after which the yoghurt was set. Plates 1 to 3 show the set yoghurt flavoured with African bush mango juice and pulp. 


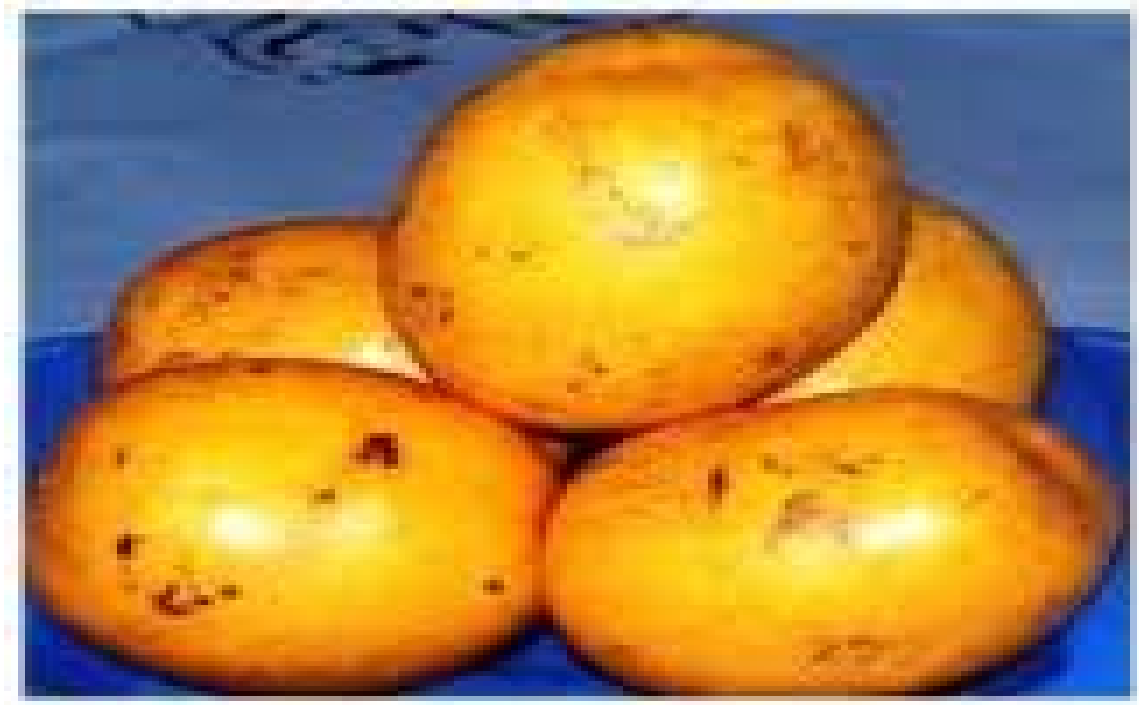

Plate 1. Ripe African bush mango fruit

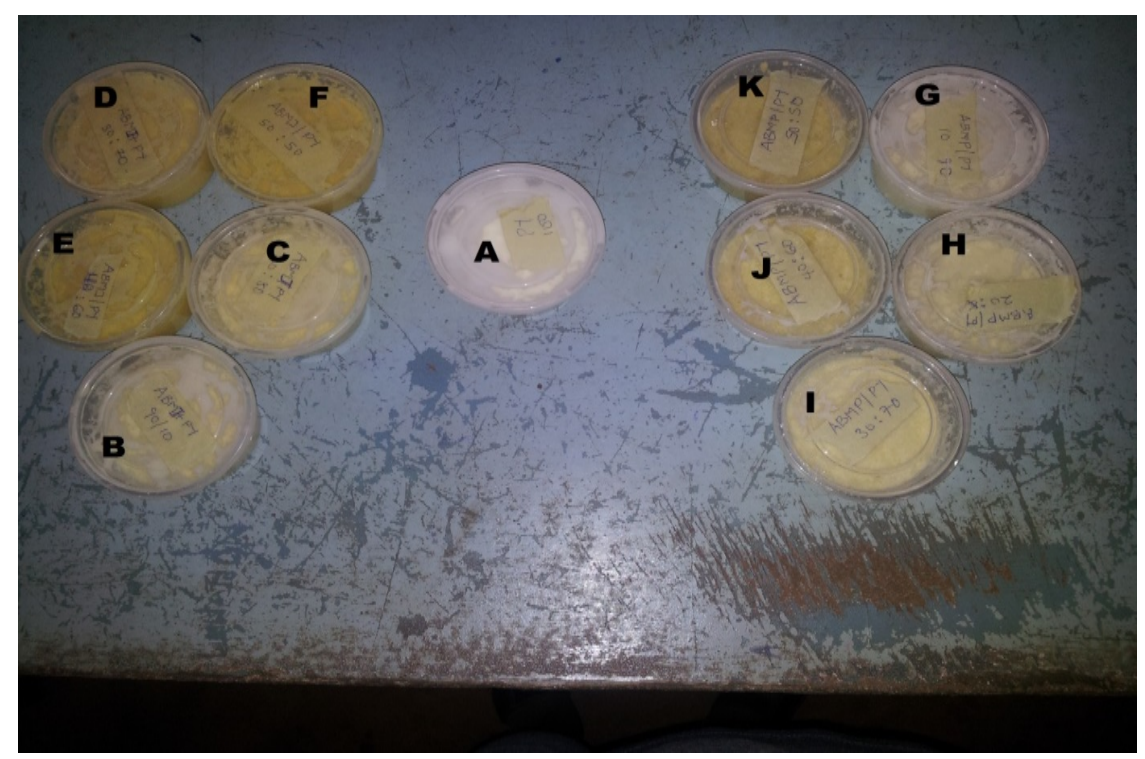

Plate 1. The formulated African bush mango flavoured yoghurt after fermentation.

PY: Plain yoghurt; ABMJ: African bush mango juice; ABMP: African bush mango pulp
A: PY (100)
B: PY+ABMJ (90:10)
G: PY+ABMP $(90: 10)$
C: PY+ABMJ $(80: 20)$
H: PY+ABMP (80:20)
D: PY+ABMJ (70:30)
I: PY+ABMP (70:30)
E: PY+ABMJ (60:40)
J: PY+ABMP (60:40)
F: PY+ABMJ (50:50)
K: PY+ABMJ (50:50) 

African Bush Mango "Ugiri" (Irvingia gabonensis) Juice and Pulp

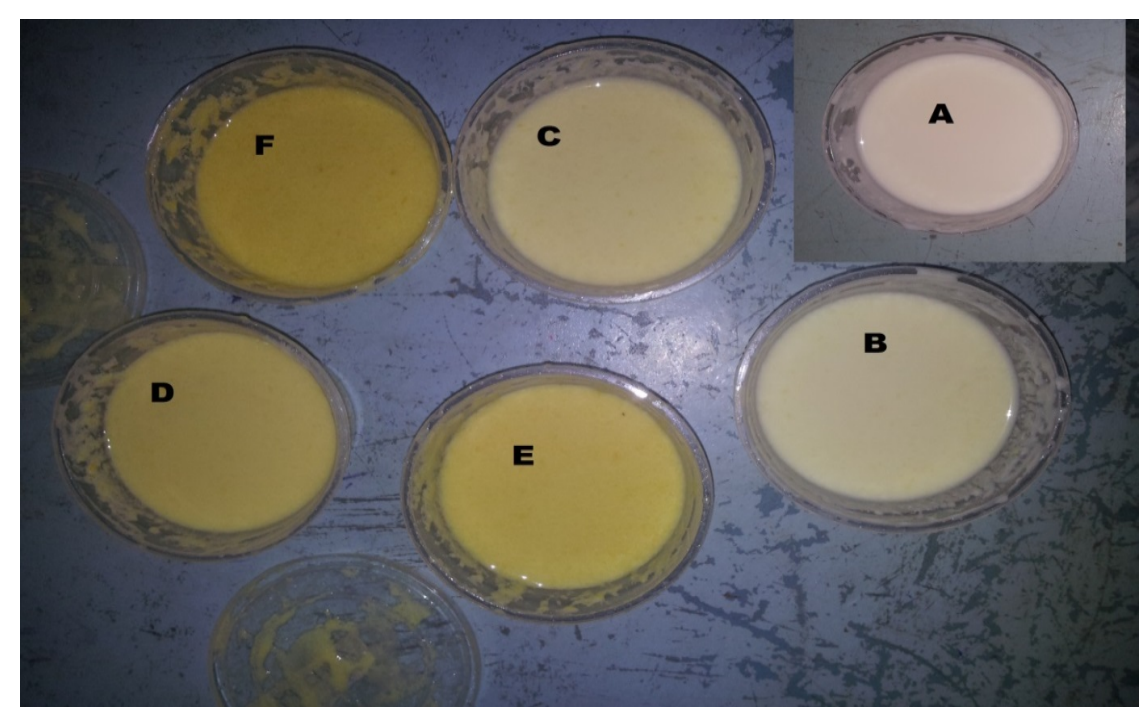

Plate 2. The formulated African bush mango juice flavoured yoghurt

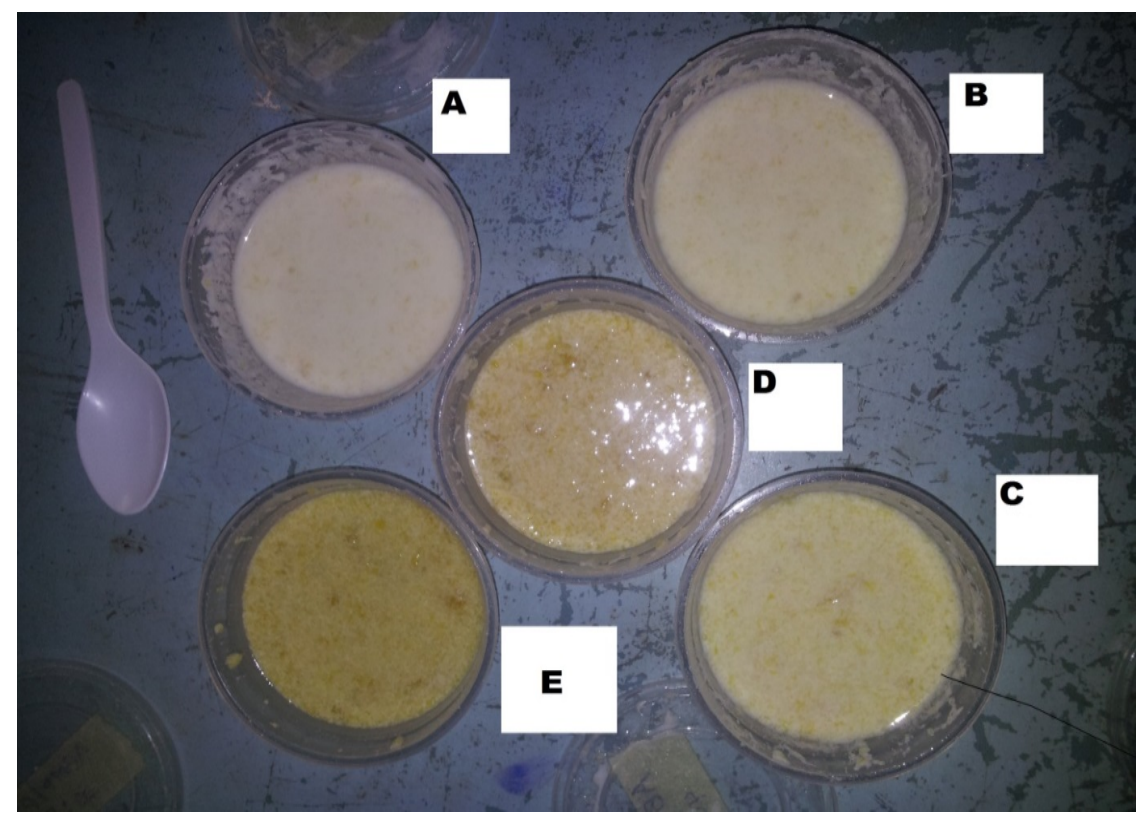

Plate 3. The formulated African bush mango pulp flavoured yoghurt

$\mathrm{A}=\mathrm{PY}(100)$;

$\mathrm{B}=\mathrm{PY}+\mathrm{ABMJ}(90: 10)$;

$\mathrm{C}=\mathrm{PY}+\mathrm{ABMJ}(80: 20)$;

$\mathrm{D}=\mathrm{PY}+\mathrm{ABMJ}(70: 30)$;

$\mathrm{E}=\mathrm{PY}+\mathrm{ABMJ}(60: 40)$;

$\mathrm{F}=\mathrm{PY}+\mathrm{ABMJ}(50: 50)$;

$$
\begin{gathered}
\mathrm{G}=\mathrm{PY}+\mathrm{ABMP}(90: 10) \\
\mathrm{H}=\mathrm{PY}+\mathrm{ABMP}(80: 20) \\
\mathrm{I}=\mathrm{PY}+\mathrm{ABMP}(70: 30) \\
\mathrm{J}=\mathrm{PY}+\mathrm{ABMP}(60: 40) ; \\
\mathrm{K}=\mathrm{PY}+\mathrm{ABMJ}(50: 50 .
\end{gathered}
$$




\subsection{Sample Analyses}

\subsubsection{Determination of Moisture Content of the Formulated Flavoured Yoghurt}

The moisture content of the samples was determined using the hot oven method of [17]. Two millilitres $(2 \mathrm{ml})$ of each sample was put into a washed and dried crucible dish and placed in a Phoenix oven (Preiser model, New York, USA) at a temperature of $70-80^{\circ} \mathrm{C}$ for 2 hours and at $100-105{ }^{\circ} \mathrm{C}$ until the weight is constant. The samples were cooled in a desiccator and weighed. The weight loss was obtained as the moisture content and was calculated as:

$$
\% \text { Moisture content }=\frac{W_{2}-W_{3} \times 100}{W_{2}-W_{1}}
$$

Where; $\mathrm{W}_{1}=$ initial weight of empty crucible; $\mathrm{W}_{2}=$ weight of crucible + sample before drying; $\mathrm{W}_{3}=$ final weight of crucible + sample after drying

\subsubsection{Determination of Crude Protein Content of the Formulated Flavoured Yoghurt}

The crude protein of the samples was determined by the semi-micro Kjeldahl technique described by [17]. A millilitre $(1.0 \mathrm{ml})$ of the sample was put into a Kjeldahl flask. Three grams (3g) anhydrous sodium sulphate and one (1g) of hydrated copper sulphate (catalyst) were added into the flask. Then, $20 \mathrm{ml}$ of concentrated tetraoxosulphate (IV) acid $\left(\mathrm{H}_{2} \mathrm{SO}_{4}\right)$ was added to digest the sample. The digestion continued under heat until a solution was observed. The clear solution was then cooled and made up to $100 \mathrm{ml}$ with distilled water and a digest of about $5 \mathrm{ml}$ was collected for distillation. Then, $5 \mathrm{ml}$ of $60 \%$ sodium hydroxide $(\mathrm{NaOH})$ was put into the distillation flask and distillation was allowed to take place for some minutes. The ammonia distilled off was absorbed by boric acid indicator and this was titrated with $0.01 \mathrm{M}$ hydrochloric acid $(\mathrm{HCl})$. The titre value of the end point at which the colour changed from green to pink was taken. The crude protein was calculated as:

$$
\% \text { Crude protein }=\frac{0.0001401 \times T \times 100 \times 6.25}{W \times 5}
$$

Where; $\mathrm{T}=$ titre value; $\mathrm{W}=$ weight of sample dried

\subsubsection{Determination of Crude Fiber Content of the Formulated Flavoured Yoghurt}

Crude fiber was dome using the method of [18]. Two millilitres $(2 \mathrm{ml})$ of the sample was hydrolysed in beaker with $299 \mathrm{ml}$ of $1.25 \%$ sulphuric acid $\left(\mathrm{H}_{2} \mathrm{SO}_{4}\right)$ and boiled for 30 minutes. The mixture was filtered, washed with hot distilled water and boiled again for 30 minutes with $200 \mathrm{ml}$ of $1.25 \%$ of $\mathrm{NaOH}$. The digested sample was also washed with $1 \%$ $\mathrm{HCl}$ acid to neutralize the $\mathrm{NaOH}$ and then with hot distilled water for several times. The residue was put into weighed crucible and dried at $100{ }^{0} \mathrm{C}$ for 2 hours in an air oven, after drying the sample was cooled, weighed and then transferred into a muffle furnace (Coleman WAKMO11379 New York,
USA) for burning at $500^{\circ} \mathrm{C}$ for 5 hours. The loss in weight was taken and percentage crude fiber was calculated as follow

$$
\begin{aligned}
& \text { Percent crude fiber }= \\
& =\frac{\text { Loss in weight }(\mathrm{g}) \text { after ignition }}{\text { Weight of the original sample }} \times 100
\end{aligned}
$$

\subsubsection{Determination of Crude Fat Content of the Formulated} Flavoured Yoghurt

The solvent extraction method as described by [17] was used. The extraction flasks were washed with petroleum ether, dried and cooled and weighed. Five millilitres (2 ml) of the sample were weighed into the extraction thimble. It was then placed back in the Soxhlet apparatus. The washed flask was filled to about three quarter of its volume with petroleum ether (that has the boiling temperature range of $40-60^{\circ} \mathrm{C}$ ). The apparatus was then set-up and extraction carried out for a period of 4 - 6 hours after which complete extraction was made. The petroleum ether was recovered leaving only oil in the flask at the end of the extraction. The oil in the extraction flask was dried in the oven, cooled and finally weighed. The fat content was expressed as a percentage of raw materials. The difference in weight of empty flasks and the flask with oil content which was calculated as:

$$
\% \text { Fat content }=\frac{C-B}{A} \times 100
$$

Where; $\mathrm{A}=$ Weight of sample; $\mathrm{B}=$ Weight of empty flask; $\mathrm{C}=$ Weight of flask + Oil.

\subsubsection{Determination of Ash Content of the Formulated Flavoured Yoghurt}

The ash content of the sample was determined by the method recommended by [17]. A silica dish was heated to about $60{ }^{0} \mathrm{C}$, cooled in a desiccator and weighed. Five millilitres $(5 \mathrm{ml})$ of the sample was put into the silica dish and transferred to the furnace. The temperature of the furnace was then allowed to reach about $525{ }^{\circ} \mathrm{C}$ after placing the dish in it. The temperature was maintained until whitish-grey colour was obtained indicating that all the organic matter content of the sample has been destroyed. The dish was then brought out from the furnace and cooled in the desiccator and re-weighed. The percentage ash content was the calculated as

$$
\text { Percentage ash content }=\frac{C-A}{B-A} \times 100
$$

Where: $\mathrm{A}=$ weight of empty dish; $\mathrm{B}=$ weight of empty dish + sample before ashing; $\mathrm{C}=$ weight dish + ash

\subsubsection{Determination of Carbohydrate of the Formulated Flavoured Yoghurt}

Carbohydrate was determined as the nitrogen free extraction calculated by difference as described by [19]. The 
formula below was used:

$$
\begin{gathered}
\% \text { Carbohydrate }=100 \%-\%(\text { protein }+ \\
+ \text { fat }+ \text { fibre }+ \text { ash }+ \text { moisture })
\end{gathered}
$$

\subsubsection{Determination of $\mathrm{pH}$ of the Formulated Flavoured Yoghurt}

The $\mathrm{pH}$ was determined using a $\mathrm{pH}$ meter as described by [17]. The electrode was dipped into the yoghurt solution and then the $\mathrm{pH}$ was recorded.

\subsubsection{Determination of Total Titrable Acidity (TTA) of the Formulated Flavoured Yoghurt}

The total titrable acidity was determined by the method described by [17]. Then, $10 \mathrm{ml}$ of the sample was measured into a conical flask and about 3 drops of phenolphthalein indicator was added to the sample and titrated with $0.1 \mathrm{~N}$ sodium hydroxide $(\mathrm{NaOH})$ until colour change was observed. The end point was taken and the TTA expressed as \% lactic acid was given as

$$
\begin{aligned}
& \% \text { TTA as lactic acid }= \\
& =\frac{m(\mathrm{NaOH}) \times N(\mathrm{NaOH}) \times 0.09 \times 100}{\text { Volume of sample }}
\end{aligned}
$$

\subsubsection{Determination of Vitamin A Content of the Formulated Flavoured Yoghurt}

Vitamin A content was determined according to [20] procedure. Then, $5 \mathrm{ml}$ sample was first saponified using an alcoholic solution of potassium hydroxide in the presence of pyrogallol. This freed the vitamins from the food matrix and converted any retinyl ester to retinol. The unsaponified matter containing vitamin A was extracted using a mixture of diethyl ether and petroleum spirit. The extract was evaporated under nitrogen and the residue was dissolved in methanol. The extract was chromatographed using a reverse phase octadecyl silane (ODS) column with the mobile phase consisting of $95 \%$ acetonitrile with $5 \%$ water. The separated retinol was then quantified using a UV absorbance detector at $328 \mathrm{~nm}$.

\subsubsection{Determination of Vitamin C Content of the Formulated Flavoured Yoghurt}

The ascorbic acid was determined using the method of [21]. Then, two millilitres $(2 \mathrm{ml})$ of the sample was weighed and $100 \mathrm{ml}$ of distilled water was added to it. It was then filtered to get a clear solution. Also, $10 \mathrm{ml}$ of the clear solution was pipette into small flask in which $2.5 \mathrm{ml}$ acetone was added. It was then titrated with indophenols solution (2, 6-dicholorophenolindophenol) to a faint pink colour which persists for 15 seconds. The vitamin $\mathrm{C}$ content was calculated as:

Vitamin C (mg/ 100ml of sample $)=20 \times \mathrm{V} \times \mathrm{C}$

Where: $\mathrm{V}=$ indophenols solution in titration $(\mathrm{ml}) ; \mathrm{C}=\mathrm{mg}$ Vitamin $\mathrm{C} / \mathrm{ml}$ indophenols

\subsubsection{Determination of Calcium Content of the Formulated} Flavoured Yoghurt

It was determined by titration method according to [18]. Then, two millilitres $(2 \mathrm{ml})$ of the ashed sample was diluted with $3 \mathrm{ml}$ of distilled water and $1 \mathrm{ml}$ of $50 \%$ ammonium oxalate. One drop of methyl red indicator was made alkaline with ammonia drops and drops of glacial acetic acid until colour changes to pink. It was stood for 4 hours and centrifuged for 5 minutes, followed by decantation of the supernatant. One millilitre $(1 \mathrm{ml})$ of hydrogen sulphate was added to the residue which was diluted with $4 \mathrm{ml}$ of distilled water. The solution was boiled and titrated with $0.02 \mathrm{~N}$ potassium permanganate.

\subsubsection{Microbial Analysis of the Formulated Flavoured Yoghurt}

\subsubsection{Determination of Total Viable Count of the Formulated Flavoured Yoghurt}

One Ringer tablet was dissolved in distilled water $(500 \mathrm{ml})$. The clear solution formed was sterilized by autoclaving for 15 minutes at $121^{\circ} \mathrm{C}$ and $15 \mathrm{lb}$ pressure. The Ringer solution was allowed to cool completely to a temperature of about $28 \pm 2^{\circ} \mathrm{C}$. The total viable count test was carried out using [22]. Using of sample and sterilized quarter strength ringer solution as diluents, $1 \mathrm{ml}$ of the sample and $9 \mathrm{ml}$ ringer solution was made serial dilutions $\left(10^{-4}\right)$. The diluted sample was pipetted into a marked Petri dish, swirled to mix and incubated at the temperature of about $37^{\circ} \mathrm{C}$ for $24 \mathrm{~h}$. After incubation, the number of colonies was counted and represented as colony forming unit per millilitre.

\subsubsection{Determination of Lactic Acid Bacteria (LAB) of the Formulated Flavoured Yoghurt}

The microbial count of lactic acid bacteria (LAB) in the formulated yoghurt was determined using deMan Rogosa Sharpe (MRS) agar (CM 361) according to [23]. Samples were serially diluted in duplicates using the surface pour plate method. The plates were incubated under anaerobic conditions at $37^{\circ} \mathrm{C}$ for 48 hours.

\subsection{Sensory Evaluation of the Formulated Flavoured Yoghurt}

Sensory properties of the samples were evaluated by 20 semi-trained panelists who are conversant with yoghurt and consisting of staff and students of University of Nigeria, Nsukka for various sensory attributes (colour, taste, flavour, texture and overall acceptability). The extent of differences between the yoghurt samples for each sensory quality was measured on a nine-point Hedonic scale, where "9" represents extremely like and " 1 " represents extremely dislike [24].

\subsection{Data Analysis and Experimental Design}


Data analyses were calculated using one-way Analysis of Variance (ANOVA) laid on a completely randomized design. Significant means were separated by Duncan's new multiple range test and significance was accepted at $(\mathrm{P}<0.05)$ using SPSS (Statistical Package for Social Sciences) version 20 according to [25].

\section{Results and Discussion}

\subsection{Proximate Composition of Yoghurt Flavoured with Graded Levels of African bush mango Juice and Pulp}

Table 1 shows the proximate composition (\%) of yoghurt flavoured with graded levels of African bush mango juice and pulp. The moisture content of the flavoured yoghurt sample ranged from $85.28-87.14 \%$ (Table 1). There was no significant $(\mathrm{p}<0.05)$ difference in the moisture contents of samples with sample PY+ABMJ (100: 0, 90:10 and 80:20), respectively. However, sample PY+ABMP $(80: 20)$ had the lowest moisture content while the sample PY+ABMJ (70:30) had the highest moisture content. This showed that the moisture levels decreased with increase in the concentration of African bush mango pulp added and increased with increase in the concentration of African bush mango juice added except for sample PY+ABMJ (80:20). This could be caused by alteration in the volume of African bush mango juice added. The decrease in the high moisture content of the formulated yoghurt sample could be as result of reduction in volume of yoghurt with increase in the volume of African bush mango juice. The moisture content of sample with ranged $85.28-87.14 \%$ observed in this study agreed with the moisture content sample with range $80.45-90.47 \%$ for formulated yoghurt flavored with solar-dried bush mango pulp reported by [26].

Table1 showed that the crude protein ranged from 1.29 $3.52 \%$ with plain yoghurt having the highest crude protein content. The protein content of the flavoured yoghurt decreased with increase in the level of African bush mango juice and pulp added. This decrease could be attributed to the lower protein content of African bush mango juice and pulp compared to milk. The protein content of the plain yoghurt agreed with the range $(3.4-5.6 \%)$ reported by [27]. The protein content of the plain yoghurt sample $\mathrm{PY}+\mathrm{ABMJ}$ (100:0) observed in this study concurred with that of the protein content of 3.5 for plain soymilk yoghurt reported by [28].

Table 1 showed that the crude fat ranged from $0.14-0.70 \%$ with plain yoghurt having the highest crude fat content. The maximum crude fat was seen in plain yoghurt sample PY+ABMJ (100:0) and fat content was found to gradually decrease with addition of the fruit juice and pulp. [29] reported that intake of African bush mango supplement boost the breakdown of fats. [29] reported that intake of African bush mango supplement boost the breakdown of fats.
Generally, African bush mango contains low level of fat therefore the addition of juice and pulp might have decreased the fat percent of flavoured yoghurt. The difference in fat percentage between plain yoghurt and flavoured yoghurts were significant $(\mathrm{p}<0.05)$ while the fat content in flavoured yoghurt sample PY+ABMJ (70:30) and PY+ABMP (90:10) were not significantly $(\mathrm{p}<0.05)$ different. The fat content of yogurts varies depending on the product, ranging from approximately $10 \%$ fat for full fat Greek style yogurts, $3 \%$ fat for whole milk yogurts, $1.7 \%$ fat for low fat yogurts and non-fat varieties containing less than $0.3 \%$ fat [30]. Therefore, the formulated sweet variety of African bush mango juice and pulp flavoured yoghurt which had a fat content ranging from 0.14 to $0.70 \%$ could be referred to as non-fat yoghurt. The fat content of the samples observed in this study concurred with the range of $0.15-0.80 \%$ for flavoured yoghurt with tamarind reported by [31].

Table 1 showed that the ash content ranged from $0.18 \%$ in sample PY+ABMJ (80:20) and PY+ABMJ (70:30) to $0.30 \%$ in sample PY+ABMJ (100:0). The ash content of African bush mango juice flavoured yoghurt samples were somewhat lower than that of plain yoghurt but differences in ash content between flavoured yoghurt sample $\mathrm{PY}+\mathrm{ABMJ}$ $(80: 20)$ and $P Y+A B M J(70: 30)$ was not significant $(p<0.05)$. Same goes with sample PY+ABMP (90:10) and PY+ABMP $(80: 20)$. The ash content differed significantly $(p<0.05)$ from range (1.21-1.38\%) for flavoured yoghurt with soursop reported by [32]. The ash content of the samples was observed to decrease with increasing level of African bush mango juice and pulp added. This could be as attributed to the decrease in the volume of milk using African bush mango juice and pulp as a substitute. According to [33] ash could be residue remaining after water and organic matter have been removed by heating in the presence of oxidizing agents, which provides a measure of the total amount of minerals present within a food. Milk is highly rich in minerals some of which are not found in African bush mango juice and pulp. This; therefore; could have instigated that the decrease in ash content with the addition of African bush mango juice and pulp. However, this decrease in ash content was minimal.

Table 1 revealed that the fibre content ranged from $1.26 \%$ in sample PY+ABMJ $(70: 30)$ to $2.87 \%$ in sample PY+ABMP (90:10). There was no significant $(\mathrm{p}<0.05)$ difference in the fibre contents of samples with PY and PY+ABMP ratios of 100:0 and 70:30, respectively, same goes with flavoured yoghurt samples PY+ABMJ (90:10) and (80:20).

Carbohydrate content ranged from $8.00 \%$ in sample PY $(100: 0)$ to $11.25 \%$ in sample PY+ABMP (80:20) as shown in Table 1 . The carbohydrate content increased with increase in the concentration of the African bush mango pulp in the flavoured yoghurt. The carbohydrate content of the African bush mango pulp flavoured yoghurt sample (PY+ABMP) 80:20 was the highest. This could probably be due to the fact that African bush mango pulp has high carbohydrate content $15.63 \mathrm{~g}$ in $100 \mathrm{~g}$ [12]. 
Table 1. Proximate composition (\%) of African bush mango juice and pulp flavoured yoghurt samples

\begin{tabular}{|c|c|c|c|c|c|c|}
\hline Sample & Moisture & Crude protein & Ash & Crude fat & Crude fibre & Carbohydrate \\
\hline PY (100:0) & $86.18^{\mathrm{b}} \pm 0.04$ & $3.52^{\mathrm{d}} \pm 0.04$ & $0.30^{\mathrm{d}} \pm 0.02$ & $0.70^{\mathrm{e}} \pm 0.01$ & $1.31^{\mathrm{a}} \pm 0.01$ & $8.00^{\mathrm{a}} \pm 0.02$ \\
\hline PY+ABMJ (90:10) & $86.19^{\mathrm{b}} \pm 0.02$ & $3.29^{\mathrm{c}} \pm 0.02$ & $0.21^{\mathrm{b}} \pm 0.01$ & $0.50^{\mathrm{d}} \pm 0.01$ & $1.48^{\mathrm{b}} \pm 0.06$ & $8.34^{\mathrm{b}} \pm 0.01$ \\
\hline PY+ABMJ (80:20) & $86.16^{\mathrm{b}} \pm 0.10$ & $2.42^{\mathrm{b}} \pm 0.00$ & $0.18^{\mathrm{a}} \pm 0.00$ & $0.44^{\mathrm{c}} \pm 0.00$ & $1.45^{\mathrm{b}} \pm 0.00$ & $9.35^{\mathrm{d}} \pm 0.11$ \\
\hline PY+ABMJ (70:30) & $87.14^{\mathrm{d}} \pm 0.10$ & $2.42^{\mathrm{b}} \pm 0.00$ & $0.18^{\mathrm{a}} \pm 0.00$ & $0.26^{\mathrm{b}} \pm 0.01$ & $1.26^{\mathrm{a}} \pm 0.06$ & $8.81^{\mathrm{c}} \pm 0.21$ \\
\hline PY+ABMP (90:10) & $86.57^{\mathrm{c}} \pm 0.08$ & $2.43^{\mathrm{b}} \pm 0.10$ & $0.26^{\mathrm{c}} \pm 0.00$ & $0.24^{\mathrm{b}} \pm 0.01$ & $2.87^{\mathrm{d}} \pm 0.02$ & $7.65^{\mathrm{a}} \pm 0.18$ \\
\hline PY+ABMP (80:20) & $85.28^{\mathrm{a}} \pm 0.21$ & $1.29^{\mathrm{a}} \pm 0.00$ & $0.25^{\mathrm{c}} \pm 0.01$ & $0.14^{\mathrm{a}} \pm 0.00$ & $1.80^{\mathrm{c}} \pm 0.05$ & $11.25^{\mathrm{e}} \pm 0.27$ \\
\hline
\end{tabular}

Values are mean \pm standard deviation of duplicate readings. Values on the same column with different superscript are significantly different $(\mathrm{p}<0.05)$.

Key: $\mathrm{PY}=$ Plain yoghurt; $\mathrm{ABMJ}=\mathrm{African}$ bush mango juice; $\mathrm{ABMP}=\mathrm{African}$ bush mango pulp

Table 2. Selected vitamins and mineral composition of African bush mango juice and pulp flavoured yoghurt

\begin{tabular}{|c|c|c|c|c|}
\hline Sample & Vitamin A (IU) & Vitamin C (mg/100g) & Phosphorus (mg/100g) & Calcium (mg/100g) \\
\hline PY+ABMJ (100:0) & $20.88^{\mathrm{a}} \pm 0.47$ & $22.20^{\mathrm{a}} \pm 0.01$ & $73.59^{\mathrm{f}} \pm 0.52$ & $62.14^{\mathrm{f}} \pm 0.21$ \\
\hline PY+ ABMJ (90:10) & $60.60^{\mathrm{c}} \pm 1.98$ & $24.80^{\mathrm{b}} \pm 0.05$ & $43.83^{\mathrm{b}} \pm 0.10$ & $38.67^{\mathrm{e}} \pm 0.00$ \\
\hline PY+ ABMJ (80:20) & $72.78^{\mathrm{d}} \pm 2.17$ & $25.54^{\mathrm{c}} \pm 0.16$ & $42.39^{\mathrm{b}} \pm 0.55$ & $35.96^{\mathrm{d}} \pm 0.63$ \\
\hline PY+ ABMJ (70:30) & $98.71^{\mathrm{f}} \pm 1.16$ & $27.79^{\mathrm{d}} \pm 0.18$ & $32.44^{\mathrm{a}} \pm 0.36$ & $33.57^{\mathrm{c}} \pm 0.99$ \\
\hline PY+ ABMP (90:10) & $26.60^{\mathrm{b}} \pm 2.90$ & $22.58^{\mathrm{a}} \pm 0.18$ & $65.71^{\mathrm{e}} \pm 0.03$ & $19.60^{\mathrm{b}} \pm 0.41$ \\
\hline PY+ ABMP (80:20) & $79.10^{\mathrm{e}} \pm 3.25$ & $22.60^{\mathrm{a}} \pm 0.55$ & $64.61^{\mathrm{d}} \pm 0.55$ & $16.99^{\mathrm{a}} \pm 0.21$ \\
\hline
\end{tabular}

Values are mean \pm standard deviation of duplicate readings. Means on the same column with different superscripts are significantly different $(\mathrm{p}<0.05)$.

KEY: $\mathrm{PY}=$ Plain yoghurt; $\mathrm{ABMJ}=\mathrm{African}$ bush mango juice; $\mathrm{ABMP}=\mathrm{African}$ bush mango Key: $\mathrm{PY}=$ Plain yoghurt; $\mathrm{ABMJ}=\mathrm{African}$ bush mango juice; $\mathrm{ABMP}=\mathrm{African}$ bush mango pulp

\subsection{Micro-nutrient Composition of Yoghurt Flavoured with Graded Levels of African bush mango Juice and Pulp}

The selected vitamins and minerals composition of the flavoured yoghurt samples are shown in Table 2. It shows the effect of African bush mango flavour on micronutrients content of the formulated sample. The vitamin A content ranged from 26.60- 98.71 IU. The plain yoghurt sample PY+ABMJ (100:0) had the lowest vitamin A content while sample PY+AMBJ (70:30) had the highest value. However, there was significant $(\mathrm{p}<0.05)$ difference in the vitamin $\mathrm{A}$ content of the samples PY $(100: 0)$ and the formulated flavoured yoghurt samples. The vitamin A content increased with increase in the addition of African bush mango juice and pulp compared to the vitamin A content of the plain yoghurt sample PY+ABMJ (100:0). This is probably due to the vitamin A content of African bush mango juice and pulp. The result range (26.60 - $98.71 \mathrm{IU})$ observed in this study concurred with the value range (35.02-280.18 IU) reported by [26]. The result also showed that the African bush mango juice contained more vitamin A than its pulp.

The ascorbic acid (vitamin C) content (Table 2) had a range between $22.20 \mathrm{mg} / 100 \mathrm{~g}$ in plain yoghurt and $27.79 \mathrm{mg} / 100 \mathrm{~g}$ in the sample flavoured with $30 \%$ African bush mango juice. The ascorbic acid content increased with the addition of African bush mango juice and pulp. This is probably due to the high ascorbic acid content of African bush mango juice and pulp. The flavoured yoghurt samples with African bush mango juice contained higher amount of vitamin $\mathrm{C}$ compared those flavoured with the pulp. Studies had shown that ascorbate favours iron absorption by reducing the inorganic iron III (ferric) complexes in food to iron II (ferrous), a form in which it is more readily absorbed according to [34]. Vitamin C (ascorbic acid) content of formulated yoghurt samples flavored with solar- dried bush mango pulp reported by [26] was far lower than that obtained in this study.

Phosphorus $(\mathrm{P})$ content is ranged from $32.44 \mathrm{mg} / 100 \mathrm{~g}$ in the sample containing with $30 \%$ African bush mango juice to $73.59 \mathrm{mg} / 100 \mathrm{~g}$ in sample plain yoghurt (Table 2). Phosphorus content decreased with increase in concentration of the African bush mango juice content of the yoghurt. Also, phosphorus decreased with increase in concentration of African bush mango pulp compared with the plain yoghurt. The plain yoghurt had the highest phosphorus content (73.59 $\mathrm{mg} / 100 \mathrm{~g})$. There was significant $(\mathrm{p}<0.05)$ difference in phosphorus content of the flavoured samples. Table 2 showed that the calcium $(\mathrm{Ca})$ content of the samples ranged between $16.99 \mathrm{mg} / 100 \mathrm{~g}$ of the formulated yoghurt with African bush mango pulp to $62.14 \mathrm{mg} / 100 \mathrm{mg}$. Plain yoghurt had the highest calcium content. There was significant $(\mathrm{p}<$ 0.05 ) difference in the calcium content of the plain yoghurt sample and the samples. The lower level of calcium in the samples containing African bush mango juice and pulp could be attributed to the substitution of milk with African bush mango juice and pulp which has lower calcium content. [35] reported that, African bush mango juice had a calcium content of $4.0 \mathrm{mg} / 100 \mathrm{~g}$ and $20 \mathrm{mg} / 100 \mathrm{~g}$ reported by [8]. Plain Yoghurt however contains $120.8 \mathrm{mg}$ of calcium per $100 \mathrm{~g}[36]$. 


\subsection{Physico-chemical Properties of Yoghurt Flavoured with Graded Levels of African bush mango Juice and Pulp}

Table 3 shows some selected physico-chemical of yoghurt flavoured with graded levels of African bush mango juice and pulp. Table 3 showed that the $\mathrm{pH}$ of the flavoured yoghurt samples ranged from 4.77 in sample PY+ABMJ (100:0) and 5.01 in sample PY+AMBJ (70:30). The flavoured yoghurt samples had slightly higher $\mathrm{pH}$ values than plain yoghurt but this difference was not significant $(\mathrm{p}<$ 0.05). Addition of African bush mango juice and pulp slightly lowered the acidity of the yoghurts and this was however in contrast with the report given by [37] whose results indicated that the use of indigenous fruits as flavours resulted in a slight increase in the acidity of yoghurts. It was also observed that addition of African bush mango juice resulted to a more less acidic yoghurt compared to that of the African bush mango pulp this, might be attributed to the $\mathrm{pH}$ of the African bush mango juice which was observed to be slightly acidic. The $\mathrm{pH}$ value of formulated yoghurt with African bush mango juice concentration of $30 \%$ agreed with the value (5.49) reported by [35]. The decrease in acidity could probably be attributed to fact that the acidity of fruits decrease as they ripen.
Total solids increased with increase in concentration of the African bush mango pulp in yoghurt. Sample PY+AMBP (80:20) had the highest total solids content (14.24\%). [31] reported total solids values for yoghurts flavoured with tamarind ranging from $(13.12-21.78 \%)$. Similar results ranged from $13.00 \%$ to $14.24 \%$ were obtained from this study. The total solids value obtained in this study was lower than that reported on yoghurt flavoured with solar-dried bush mango (Irvingia gabonensis) pulp by [26]. This could be attributed to the nature of the African bush mango used in this study (juice and wet pulp). The difference between the total solids of the formulated yoghurt sample and the plain yoghurt sample was not significant $(p<0.05)$. Furthermore, moisture content in Table 1 decreased with increase in the total solids. For instance sample PY+ABMP $(80: 20)$ in Table 1 had lowest moisture content and the highest total solids content in Table 3.

Table 3 showed that the titrable acidity of samples decreased with increase in the $\mathrm{pH}$ values. Titrable acidity ranged from $0.76 \%$ in sample $\mathrm{PY}+\mathrm{ABMJ}(70: 30)$ to $0.91 \%$ in sample PY+ABMP (90:10). [32] reported titrable acid values for soursop pulp flavoured yoghurts ranging from $0.69-0.83 \%$. Similar results $0.76-0.91 \%$ were obtained from this study.

Table 3. Physico-chemical properties of African bush mango flavoured yoghurt samples

\begin{tabular}{|c|c|c|c|c|}
\hline Sample & $\mathrm{pH}$ & Titrable acidity & Total solids (\%) & Reducing sugar(\%) \\
\hline PY+ABMJ 100:0 & $4.77^{\mathrm{a}} \pm 0.11$ & $0.85^{\mathrm{cd}} \pm 0.01$ & $13.85^{\mathrm{ab}} \pm 0.07$ & $9.33^{\mathrm{a}} \pm 0.07$ \\
\hline PY+ ABMJ (90:10) & $4.78^{\mathrm{a}} \pm 0.18$ & $0.83^{\mathrm{bc}} \pm 0.00$ & $13.85^{\mathrm{ab}} \pm 0.02$ & $9.85^{\mathrm{ab}} \pm 0.02$ \\
\hline PY+ ABMJ (80:20) & $4.79^{\mathrm{a}} \pm 0.27$ & $0.80^{\mathrm{b}} \pm 0.01$ & $13.84^{\mathrm{ab}} \pm 0.10$ & $10.80^{\mathrm{bc}} \pm 0.10$ \\
\hline PY+ ABMJ (70:30) & $5.01^{\mathrm{a}} \pm 0.21$ & $0.76^{\mathrm{a}} \pm 0.02$ & $13.00^{\mathrm{a}} \pm 0.10$ & $10.20^{\mathrm{abc}} \pm 0.10$ \\
\hline PY+ ABMP (90:10) & $4.69^{\mathrm{a}} \pm 0.12$ & $0.91^{\mathrm{e}} \pm 0.01$ & $13.55^{\mathrm{ab}} \pm 0.07$ & $10.90^{\mathrm{c}} \pm 0.28$ \\
\hline PY+ ABMP (80:20) & $4.80^{\mathrm{a}} \pm 0.01$ & $0.88^{\mathrm{de}} \pm 0.02$ & $14.24^{\mathrm{b}} \pm 0.90$ & $12.56^{\mathrm{d}} \pm 0.10$ \\
\hline
\end{tabular}

Values are mean \pm standard deviation of duplicate readings. Means on the same column with different superscripts are significantly different $(\mathrm{P}<0.05)$. Key: $\mathrm{PY}=$ Plain yoghurt; $\mathrm{ABMJ}=\mathrm{African}$ bush mango juice; $\mathrm{ABMP}=$ African bush mango pulp 


\subsection{Microbial Count (cfu/ml) of Yoghurt Flavoured with Graded Levels of African bush mango Juice and Pulp}

Table 4 shows the microbial population of the formulated products. The samples showed a lactic acid bacteria count of between $1.2 \times 10^{5}-7.5 \times 10^{4} \mathrm{cfu} / \mathrm{ml}$. The lactic acid bacteria (LAB) count was also observed to decrease with increase in African bush mango juice and pulp concentration. This could be as a result of the decrease in milk content which contains the lactose which acts as a substrate for the growth and multiplication of the LAB. This decrease could also be responsible for the increase in $\mathrm{pH}$ observed.

As shown in Table 4 the samples showed a total viable count of between $1.2 \times 10^{5} \mathrm{cfu} / \mathrm{ml}$ in sample PY+ABMP $(80: 20)$ to $2.7 \times 10^{5} \mathrm{cfu} / \mathrm{ml}$ in plain yoghurt. The total viable count was observed to decrease with increase in African bush mango juice and pulp. This could attribute to the antimicrobial effect of African bush mango. African bush mango have inhibitory activity against several bacteria and fungi with its potential mechanisms action which include membrane disruption by terpenoids and inactivation of microbial adhesion, enzymes, and cell envelope transport proteins by ellagic acids-like compound [38].

\subsection{Sensory Scores for the Formulated Yoghurt Flavoured with Graded Levels of African bush mango Juice}

Table 5 shows the sensory scores of the yoghurt flavoured with graded levels of African bush mango juice. The mean scores of colour ranged from 3.95 in the sample containing with $50 \%$ African bush mango juice to 8.10 in plain yoghurt. Plain yoghurt had the highest score for colour and there was significant $(\mathrm{p}<0.05)$ difference in the colour of the plain yoghurt sample and the flavoured yoghurt samples. The sample containing 50\% African bush mango juice had the lowest colour value (3.95)

Table 4. Lactic acid bacteria (LAB) and total viable count (TVC)

\begin{tabular}{|c|c|c|}
\hline Sample & TVC(cfu/ml) & LAB (cfu/ml) \\
\hline PY+AMBJ(100:0) & $2.7 \times 10^{5}$ & $9.1 \times 10^{5}$ \\
\hline PY+AMBJ (90:10) & $2.0 \times 10^{5}$ & $8.5 \times 10^{4}$ \\
\hline PY+AMBJ(80:20) & $1.9 \times 10^{5}$ & $7.5 \times 10^{4}$ \\
\hline PY+AMBJ(70:30) & $1.6 . \times 10^{5}$ & $7.5 \times 10^{4}$ \\
\hline PY+AMBP(90:10) & $2.4 \times 10^{5}$ & $3.8 \times 10^{4}$ \\
\hline PY+AMBP(80:20) & $1.2 \times 10^{5}$ \\
\hline
\end{tabular}

Key: $\mathrm{PY}=$ Plain yoghurt; $\mathrm{ABMJ}=$ African bush mango juice; $\mathrm{ABMP}=\mathrm{African}$ bush mango juice pulp $\mathrm{LAB}=$ Lactic acid bacteria $\mathrm{TVC}=\mathrm{Total}$ viable count $\mathrm{pH}$ of deManRogosa Sharpe (MRS) Agar (CM 361) $=6.2 \pm 0.2$

$\mathrm{pH}$ of Nutrient agar media $=7.4 \pm 0.2$

Table 5. Sensory scores of yoghurt flavoured with graded levels of African bush mango juice

\begin{tabular}{|c|c|c|c|c|c|c|c|}
\hline Sample & Colour & Flavour & Taste & Aftertaste & Consistency & Mouthfeel & Overall Acceptability \\
\hline PY+ABMP (100:0) & $8.10^{\mathrm{d}} \pm 1.02$ & $7.75^{\mathrm{d}} \pm 0.97$ & $7.75^{\mathrm{c}} \pm 0.91$ & $7.35^{\mathrm{c}} \pm 1.04$ & $6.95^{\mathrm{c}} \pm 0.83$ & $7.50^{\mathrm{d}} \pm 0.89$ & $7.95^{\mathrm{e}} \pm 0.89$ \\
\hline PY+ABMP (90:10) & $6.70^{\mathrm{c}} \pm 1.26$ & $6.50^{\mathrm{c}} \pm 1.43$ & $6.35^{\mathrm{e}} \pm 1.46$ & $6.65^{\mathrm{c}} \pm 1.18$ & $6.60^{\mathrm{c}} \pm 1.57$ & $6.25^{\mathrm{c}} \pm 1.55$ & $6.70^{\mathrm{d}} \pm 1.30$ \\
\hline PY+ABMP (80:20) & $6.05^{\mathrm{c}} \pm 1.43$ & $5.25^{\mathrm{c}} \pm 1.29$ & $5.00^{\mathrm{e}} \pm 1.38$ & $4.95^{\mathrm{b}} \pm 1.50$ & $5.90^{\mathrm{bc}} \pm 1.33$ & $4.90^{\mathrm{b}} \pm 1.44$ & $5.30^{\mathrm{c}} \pm 1.49$ \\
\hline PY+ABMP (70:30) & $4.30^{\mathrm{b}} \pm 1.56$ & $4.75^{\mathrm{bc}} \pm 1.74$ & $4.45^{\mathrm{e}} \pm 1.50$ & $4.70^{\mathrm{b}} \pm 1.38$ & $5.15^{\mathrm{ab}} \pm 1.87$ & $3.65^{\mathrm{a}} \pm 1.30$ & $4.37^{\mathrm{c}} \pm 1.57$ \\
\hline PY+ABMP (60:40) & $3.60^{\mathrm{a}} \pm 1.67$ & $4.40^{\mathrm{ab}} \pm 1.75$ & $3.75^{\mathrm{c}} \pm 1.33$ & $4.55^{\mathrm{b}} \pm 1.53$ & $4.50^{\mathrm{a}} \pm 2.50$ & $3.35^{\mathrm{a}} \pm 1.35$ & $3.95^{\mathrm{ab}} \pm 1.70$ \\
\hline PY+ABMP ( 50:50) & $3.00^{\mathrm{a}} \pm 2.00$ & $4.175^{\mathrm{a}} \pm 1.99$ & $2.80^{\mathrm{c}} \pm 1.32$ & $3.35^{\mathrm{a}} \pm 1.79$ & $4.20^{\mathrm{a}} \pm 2.50$ & $3.00^{\mathrm{a}} \pm 1.92$ & $3.30^{\mathrm{a}} \pm 1.92$ \\
\hline
\end{tabular}

Values are mean \pm standard deviation of 30 panelists. Means on the same column with different superscripts are significantly different $(\mathrm{P}<0.05)$. Key: $\mathrm{PY}=$ Plain yoghurt; $\mathrm{ABMJ}=\mathrm{A}$ frican bush mango juice; $\mathrm{ABMP}=$ African bush mango pulp 
The scores for flavour ranged from 3.50 in sample PY+AMBJ (50:50) to 7.75 in plain yoghurt. Plain yoghurt had the highest score (7.75) for flavour. The preference for the flavour of the products reduced with increasing level of African bush mango juice addition. Plain yoghurt had the highest score for flavour but there was no significant $(\mathrm{p}<0.05)$ difference in the flavour of the plain yoghurt sample and the sample containing $10 \%$ African bush mango juice.

The scores for taste ranged from 3.30 in sample PY+AMBJ (50:50) to 7.75 in sample plain yoghurt. Plain yoghurt had the highest score (7.75) for taste. Plain yoghurt had the highest score for taste but there was significant $(p<$ 0.05 ) difference in the taste of the plain yoghurt sample and the samples.

The values for consistency ranged from 4.30 in sample PY+ABMJ (50:50) to 6.95 in sample plain yoghurt. Plain yoghurt had the highest score (6.95) for consistency. The preference for the consistency of the products reduced with increasing level of African bush mango juice addition. Plain yoghurt had the highest score for consistency but there was no significant $(p<0.05)$ difference in the consistency of the plain yoghurt sample and the sample containing $10 \%$ African bush mango juice.

The mouthfeel ranged from 4.15 in PY+ ABMJ (50:50) to 7.50 in the plain yoghurt sample. The results show that there was no significant $(p<0.05)$ difference between mouth feel and general acceptability of the plain yoghurt and flavoured sample with containing $10 \%$ African bush mango juice.

The mean scores for overall acceptability ranged from 3.60 in sample PY+AMBJ (50:50) to 7.95 in plain yoghurt. High mean values (7.95) were obtained for the plain yoghurt for all sensory attributes (colour, flavour, taste, aftertaste, consistency and mouth feel) therefore making it the most preferred sample with an overall acceptability of 7.95 . Sample PY+ ABMJ (90:10) had the highest mean for general acceptability (7.35) compared to the other flavoured yoghurt samples and was second in overall preference. Low means were observed in the samples containing 40 and $50 \%$ African bush mango juice for all sensory attributes (colour, flavour, taste, aftertaste, consistency and mouth-feel) therefore making them the most disliked samples with an overall acceptability of 4.30 and 3.60 respectively.
The results of the sensory evaluation implied that yoghurt flavoured with up to $30 \%$ African bush mango juice could be produced without having a negative impact on the consumer acceptability of the product. Similar acceptance of flavoured yoghurt using indigenous fruits were obtained using beetroot by [39], soursop [40], cashew [41] as well as carrot, pineapple, and spiced yoghurts using ginger and pepper fruit [42]. These quality findings may be useful for yoghurt industries to produce new variety of yoghurts. Plain yoghurt was more highly rated than African bush mango juice flavoured yoghurt in all the sensory attributes. This could be attributed to the sweet to bitter taste accustomed to African bush mango rather than the African bush mango flavoured yoghurts that had never been used in yoghurt production.

\subsubsection{Sensory Scores of Yoghurt Flavoured with Graded Levels of African bush mango Pulp}

Table 6 shows the sensory scores of the yoghurt flavoured with graded levels of African bush mango. The mean scores for overall acceptability ranged from 3.30 in sample PY+AMBP (50:50) to 7.95 in plain yoghurt. High mean values (7.95) were obtained for the plain yoghurt for all sensory attributes (colour, flavour, taste, aftertaste, consistency and mouthfeel) by making it the most preferred sample with an overall acceptability of 7.95. Sample PY+ ABMJ (90:10) had the highest mean for general acceptability (6.70) compared to the other flavoured yoghurt samples and was second in overall preference. Low means were observed in the samples containing 30,40 and 50\% African bush mango juice for all sensory attributes (colour, flavour, taste, aftertaste, consistency and mouth-feel) thereby making them the most disliked samples with an overall acceptability of $4.37,3.95 \%$ and 3.30 respectively. The value for overall acceptability of 6.70 for flavoured yoghurt containing $10 \%$ African bush mango pulp was not significantly different $(\mathrm{p}<$ $0.05)$ from the value (6.75) reported for solar-dried African bush mango pulp flavoured yoghurt [26]. The results of the sensory evaluation implied that yoghurt flavoured with up to $20 \%$ African bush mango pulp could be produced without having a negative impact on the consumer acceptability of the product.

Table 6. Sensory scores of yoghurt flavoured with graded levels of African bush mango pulp

\begin{tabular}{|c|c|c|c|c|c|c|c|}
\hline Sample & Colour & Flavour & Taste & Aftertaste & Consistency & Mouthfeel & Overall Acceptability \\
\hline PY+ABMJ (100:0) & $8.10^{\mathrm{e}} \pm 1.02$ & $7.75^{\mathrm{c}} \pm 0.97$ & $7.75^{\mathrm{e}} \pm 0.91$ & $7.35^{\mathrm{d}} \pm 1.04$ & $6.95^{\mathrm{d}} \pm 0.83$ & $7.50^{\mathrm{c}} \pm 0.89$ & $7.95^{\mathrm{d}} \pm 0.89$ \\
\hline PY+ ABMJ (90:10) & $7.30^{\mathrm{d}} \pm 0.86$ & $6.90^{\mathrm{c}} \pm 1.25$ & $6.90^{\mathrm{c}} \pm 1.25$ & $7.35^{\mathrm{d}} \pm 1.04$ & $6.55^{\mathrm{cd}} \pm 1.19$ & $7.00^{\mathrm{c}} \pm 1.30$ & $7.35^{\mathrm{d}} \pm 0.98$ \\
\hline PY+ ABMJ (80:20) & $5.85^{\mathrm{c}} \pm 1.18$ & $5.15^{\mathrm{b}} \pm 1.18$ & $4.95^{\mathrm{b}} \pm 1.53$ & $5.35^{\mathrm{c}} \pm 1.34$ & $5.70^{\mathrm{bc}} \pm 0.98$ & $5.80^{\mathrm{b}} \pm 0.95$ & $6.200^{\mathrm{c}} \pm 0.83$ \\
\hline PY+ ABMJ (70:30) & $5.15^{\mathrm{bc}} \pm 1.18$ & $4.65^{\mathrm{a}} \pm 1.39$ & $4.65^{\mathrm{b}} \pm 1.39$ & $4.60^{\mathrm{bc}} \pm 1.50$ & $5.65^{\mathrm{bc}} \pm 1.57$ & $5.35^{\mathrm{b}} \pm 1.35$ & $5.15^{\mathrm{b}} \pm 1.23$ \\
\hline PY+ABMJ (60:40) & $4.60^{\mathrm{ab}} \pm 1.53$ & $4.05^{\mathrm{a}} \pm 1.50$ & $3.75^{\mathrm{a}} \pm 1.25$ & $4.10^{\mathrm{ab}} \pm 1.44$ & $4.70^{\mathrm{ab}} \pm 1.92$ & $4.90^{\mathrm{ab}} \pm 1.37$ & $4.30^{\mathrm{a}} \pm 1.63$ \\
\hline PY+ABMJ (50:50) & $3.95^{\mathrm{a}} \pm 1.31$ & $3.95^{\mathrm{a}} \pm 1.76$ & $3.30^{\mathrm{a}} \pm 1.26$ & $3.50^{\mathrm{a}} \pm 1.64$ & $4.30^{\mathrm{a}} \pm 2.36$ & $4.15^{\mathrm{a}} \pm 2.13$ & $3.60^{\mathrm{a}} \pm 1.46$ \\
\hline
\end{tabular}

Values are mean \pm standard deviation of 30 panelists. Means on the same column with different superscripts are significantly different $(\mathrm{P}<0.05)$.

Key: $\mathrm{PY}=$ Plain yoghurt; $\mathrm{ABMJ}=\mathrm{African}$ bush mango juice; $\mathrm{ABMP}=$ African bush mango pulp 


\section{Conclusions}

The result of this study showed that addition of African bush mango juice and pulp to yoghurt as flavouring agent improved the physicochemical, proximate and sensory properties of the formulated product. The flavoured yoghurt contained a good amount of vitamin $\mathrm{C}$, which is vital in iron metabolism and subsequent fight against iron deficiency anaemia (IDA). This could contribute significantly in improving the vitamin $\mathrm{C}$ intake of the populace in Nigeria. The use of underutilized natural flavour (African bush mango fruit) helps in creating a variety of yoghurt and also increasing the nutritional as well as medicinal value of yoghurt. The addition of African bush mango juice and pulp to yoghurt had a positive impact on the proximate, micronutrient and sensory properties of the formulated product. From the results obtained in this study, it can be concluded that the yoghurt blended with African bush mango juice at a ratio of 90:10 was the most preferred among the flavoured yoghurt samples formulated. It had a general acceptability of 7.15 while the blend with African bush mango pulp at a ratio of 90:10 was the most preferred among the flavoured yoghurt.

Based on the result, it is recommended that more research be carried out on the African bush mango (mesocarp) in order to improve its sensory characteristics and increasing the shelf life of the fruit juice and pulp as flavouring agents. Consumers should also be enlightened on the nutritional and health benefits of African bush mango as a strategy for food diversification and domestication of African bush mango. Further studies should also be done on the shelf stability of African bush mango flavoured yoghurt.

\section{REFERENCES}

[1] Xue Han, Zhe Yang, Xueping Jing, Peng Yu, Yingchun Zhang, Huaxi Yi, and Lanwei Zhang (2016). Improvement of the Texture of Yogurt by Use of Exopolysaccharide Producing Lactic Acid Bacteria. BioMed Research International, http://dx.doi.org/10.1155/2016/7945675

[2] Saint A, Juteau A, Atlan S, Martin N, Souction I (2006). Influence of Proteins on the Perception of Flavoured Stirred Yoghurts. Journal of Soc. Dairy Technology 30:31-32.

[3] David, B. F. (2003). Yoghurt making illustration. In: Biology and Chemistry, Clermont Science College, Batavia, pp. 45-103

[4] White, S. and White, G. (1994). Dairy flavouring. In: Food Flavouring, Ashrust P.R. (Ed), Blackie and sons Ltd, London. pp. $222-236$

[5] Ohiokpehai, O. (2003). Processed food products and nutrient composition of goat milk. Pakistan Journal of Nutrition, 2(2): $68-71$.

[6] Obatolu, V. A., Adebowale, E. A., Omidokun, F. A. and Farinde, E. O. (2007). Comparative evaluation of yoghurt samples from goats and cow milk and commercial retail outlet. Nigerian Journal of Animal Production, 34 (1):163 - 171.

[7] Fellows, P. J. (2009). Food Processing Technology: Principles and Practice $3^{\text {rd }}$ Ed., Woodhead publishing, Oxford, United Kingdom. pp. $173-175$.

[8] Anon. (2016a). Yoghurt. www. http://www.cookinfo.com/wil dmango. Accessed 28 May, 2016.

[9] Akubor, P. I. (1996). The suitability of African bush mango juice for wine production. Plant foods for Human Nutrition, 49(3): 213-219.

[10] Umoh, I. B. (1998). Commonly used fruits in Nigeria. In: Nutritional quality of foods the support zone of the korupark of Cameroon-Determining the connections between the household and the forest. CARPE: limbe non-wood forest products workshop. pp. $4-6$.

[11] Platt, B. S. (1962). Tables of representative values of foods commonly used in tropical countries. Special report series 302, Medical Research Council, London, United Kingdom. $44 \mathrm{pS}$.

[12] Anon (2016b). Bush mango. www.webmd.com/diet/features/ African. Accessed 22 September, 2016.

[13] Adams, M .R. and Moss, M. O. (1995). Fermented and microbial foods. In: Food Microbiology. The royal society publisher, UK. pp 252 - 302.

[14] Okaka, J.C. (2005). Fruit and vegetables processing In: Handling, storage and processing of plant foods. OCJ Academic publishers, Enugu. pp. 199 - 223.

[15] Ivor, H. (2002). Flavouring agent. A knowledge report, Central African regional program for environment, Herbatata publishers. New Zealand. pp. 10 - 16

[16] Woodroff, J. and Luh, B. (1986). Commercial fruit processing. 2nd ed. Chapman and Hall, London. pp. 18 - 21.

[17] AOAC (2010). Official methods of Analysis of Association of Official Analytical Chemists $18^{\text {th }}$ ed., Published by AOAC International, Gaithersburg, Maryland, USA.

[18] Kirk, R. S. and Sawyer, R. (1991). Pearsons' Composition and Analysis of Foods, $9^{\text {th }}$ ed., Longman Group Ltd, London. pp. $126-130$.

[19] Oyenuga, V. A. (1968). Nigeria's Foods and Feeding Stuff, their Chemistry and Nutritive Value. University Press, Ibadan, Nigeria. pp. 9 - 16.

[20] Prentice, G. A and Langridge, E. W. (1992). Laboratory control in milk product manufacture: Technology of dairy products. Early. R. (Ed). Blackie and Sons Ltd, London. pp. $247-269$.

[21] Osborne, D. R. and Voogt, P. (1978). The analysis of nutrients in Foods, $6^{\text {th }}$ edition Academic Press, New York. p. 251.

[22] Prescott, L. M., Harley, J. P. and Klein, O. A. (2005). Microbial nutrition, types of media, in: Microbiology, $6^{\text {th }} \mathrm{Ed}$. Mc Graw Hill Publisher, New York. pp. 95 - 105

[23] Harrigan, W. E. and McCance, M. E. (1976). Basic Methods. In: Laboratory Methods in Food and Dairy Microbiology. Academic Press, London. pp. 3 - 16.

[24] Ihekoronye, A. I. and Ngoddy P. O. (1985). Integrated Food 
Science and Technology for the Tropics. Macmillan Publishers Ltd, London. pp 368-369.

[25] Steel, R. G. D. and Torrie, J. H. 1980. Principle and procedures of statistics, 2nd edition, McGraw- Hill publishers, New York. pp. $176-183$.

[26] Mbaeyi, I. E. and Anyanwu, L. N. (2010).Production and evaluation of yoghurt flavoured with solar-dried bush mango (Irvingia gabonensis) pulp. Journal of Tropical Agriculture, Food, Environment and Extension, 9:137 - 146.

[27] Janhoj, E., Charlotte B. and Micheal B. (2006). Sensory and rheological characterization of low fat stirred yoghurt. Journal of Texture Studies, 37:276 - 299.

[28] Osundahunsi, O. F., Amosu, D. and Ifesan, B.O. T. (2007). Quality evaluation and acceptability of Soy-yoghurt with different colours and fruit flavours. American Journal of Food Technology, 2: 273 - 280 .

[29] Anon. (2016c). Irvingia gabonensis (Aubry-lecomte).www.pr ota4u.org. Retrieved on $23^{\text {rd }}$ March, 2016.

[30] Dairy council (2013). Nutrients in yoghurt. www.milk.co.uk. Accessed $5^{\text {th }}$ April, 2016.

[31] Ibanga, B. E. (2010). Development and evaluation of yoghurt flavoured with tamarind (Tamarindus indica). A B.Sc Project, Department of Food Science and Technology, University of Nigeria, Nsukka.

[32] Ekere, K. S. (2014). Production and evaluation of flavoured yoghurt from graded levels of soursop. A B.Sc. project, Department of Food Science and Technology, University of Nigeria, Nsukka.

[33] MacClements, D. J. (2003) Analysis of food products (Food Science 581). www.people.umass.edu/581Ashandminerals. Accessed on 24 June, 2016.

[34] Onimawo I. A., Oteno, F., Orokpo, G. and Akubor, P. I. (2003). Physicochemical and nutrient evaluation of African bush mango (Irvingia gabonensis) seeds and pulp. Plants Foods for Human Nutrition, 58:1-6.
[35] Belonwu, C. P. (2007). Production and evaluation of juice from "ugiri" African bush mango. A B.Sc project, Department of Food Science and Technology, University of Nigeria, Nsukka.

[36] Anon. (2016d). Dairy food and recipes; Nutritional Information. www.dairyaustralia.com Retrieved 20th September, 2016

[37] Dlamini, A. M, Mamba, R and Silaula, S. M. (2009). Attributes and consumer acceptance of yoghurt flavoured with non - cultivated indigenous Swazi fruits. African Journal of Food, Agriculture, Nutrition and Development, 9 (1):636-651.

[38] Fadere, D. A. and Ajaiyeoba, E. O. (2008). Phytochemical and antimicrobial activities of the wild mango-Irvingia gabonensis extracts and fractions. Medical science, 2: 119 124.

[39] Mbaeyi-Nwaoha, I.E and Nwachukwu, O.G. (2012). Production and Evaluation of Yoghurt Flavoured with Beetroot (Beta vulgaris L.). Journal of Food Science and Engineering 2(10): 583-592. Available online: http://davidpublishing.org or http://davidpublishing.com

[40] Mbaeyi- Nwaoha, I. E. and Ekere, K. S. (2014). Production and Evaluation of Flavored Yoghurt from Graded Levels of Soursop (Annona muricata) Pulp. Innovare Journal of Food Science 2(1): $14 \quad-21$. Also cited on http://innovareacademics.in/journals/index.php/ijfs.

[41] Mbaeyi-Nwaoha, I.E. and Iwezor-Godwin, L.C. (2015). Production and evaluation of yoghurt flavoured with fresh and dried cashew (Anacardium occidentale) apple pulp. African Journal of Food Science and Technology 6(8): 234-246. DOI:http:/dx.doi.org/10.14303/ajfst.2015.075. Available online@http://www.interesjournals.org/AJFST.

[42] Ihemeje, A., Nwachukwu, C. N. and Ekwe, C. C (2015). Production and quality evaluation of flavoured yoghurts using carrot, pineapple, and spiced yoghurts using ginger and pepper fruit. African Journal of Food Science, .9(3): 163 - 169. DOI: $10.5897 /$ AJFS2014.1244. 